\title{
CHEMICAL, CLINICAL, AND IMMUNOLOGICAL STUDIES ON THE PRODUCTS \\ OF HUMAN PLASMA FRACTIONATION. XXV. THE PREPARATION OF \\ ANTI-A ISOAGGLUTININ REAGENTS FROM MIXED \\ BLOOD OF GROUPS O AND B ${ }^{\mathbf{1 , 2}}$
}

\author{
By MARSHALL MELIN \\ (From the Department of Physical Chemistry, Harvard Medical School, Boston)
}

(Received for publication May 1, 1945)

In a previous publication (1), it has been stated that reagents for the determination of blood groups are obtained as products of the human plasma fractionation program. By a chemical procedure, the isoagglutinin-containing globulins are separated from most of the other plasma proteins, thereby enabling the use of the latter fractions for other purposes (2), and the use of the refined isoagglutinins in concentrated form for blood group examinations. The properties of the preparations obtained in this manner from groupspecific plasma have been described $(1,3)$, and the United States Navy has let contracts with the industry to procure the reagents. This laboratory served to control ${ }^{3}$ this iosagglutination production program, and so it has had the opportunity of determining what changes in methods would provide larger amounts of good quality bloodgrouping preparations.

The control of the products is based on comparison of their properties with the properties of Reference Standards. Two blood-grouping re-

1 This work has been carried out under contract, recommended by the Committee on Medical Research, between the Office of Scientific Research and Development and Harvard University.

2 This paper is Number 35 in the series "Studies on Plasma Proteins" from the Harvard Medical School, Boston, Massachusetts, on products developed by the Department of Physical Chemistry from blood collected by the American Red Cross.

3 The group of investigators in associated laboratories who have assisted regularly in the appraisal of these products includes Dr. W. C. Boyd, Boston University Medical School; Dr. L. K. Diamond, Children's Hospital, Boston; and Dr. E. L. DeGowin, University Hospitals, Iowa City. The laboratory of Capt. L. R. Newhouser has reported on behalf of the U. S. Navy. At the Harvard Medical School, the control group, under the direction of Dr. E. J. Cohn and Dr. J. L. Oncley, includes Mr. J. W. Cameron, Mr. P. M. Gross, Miss M. M. Hasson, Miss S. G. Miller, Dr. D. A. Richert, and Miss J. Sullivan. agents, one anti-A and the other anti-B, each processed by the Harvard Pilot Plant from groupspecific plasma, were adopted as Reference Standards by a committee of experts headed by Dr. E. L. DeGowin (3). Two different techniques (1) are used to compare any product with the Reference Standard of the same group. One test is designed to measure the amount of isoagglutinin by a "titration" procedure. The other technique is used to evaluate the product's "avidity," i.e., the speed of agglutination and the size of clumps obtained when the preparation is mixed with a cell suspension on a slide. Thus, preparations are judged acceptable if samples are found to be equal or superior to the Reference Standard by all tests, and if, furthermore, they are found to be "specific" for the group of cells with which they are supposed to react. Anti-B preparations are tested with $\mathrm{B}$ cells for titer and avidity. The existence of subgroups of the blood group A makes it necessary to test anti-A preparations both with $A_{1}$ and with $\mathrm{A}_{2} \mathrm{~B}$ cells. ${ }^{4}$

\section{THE CHOICE OF PLASMA TO BE PROCESSED INTO ISOAGGLUTININ REAGENTS}

In the method previously described, the production of isoagglutinins started with the collection of group-specific plasma from random donors of a single group. It was found that anti-A preparations from pools of $\mathrm{B}$ plasma were often deficient in their reactions with $\mathrm{A}_{2} \mathrm{~B}$ cells. It was recognized that the isoagglutinin titers of individuals of group $B$, for example, vary greatly, and that the potency of a pool could be increased by omitting low-titered plasma, so an attempt was made to

4 The reactions of $A_{2} B$ cells with anti-A preparations are, in general, much weaker than are those of $A_{2}$ cells; hence use of cells of the former group provides a more sensitive criterion for rejection of products weak in subgroup activity. We are indebted to Drs. L. K. Diamond and W. C. Boyd for calling our attention to this fact. 
improve the B pools by selecting the specimens to be included. An unfortunate result of this procedure was that it decreased the amount of plasma processed into blood-grouping preparations. The yield of the reagents from a given number of blood donations is already limited by the low incidence of donors of group B (Table I). A large part of the available supply of group A plasma was not needed in this program since the routine examination for blood group necessarily utilizes both kinds of isoagglutinin in equal amounts.

TABLE I

Frequency of blood groups in the United States (4)

$\begin{array}{cc}\text { Blood group } & \text { Percentage of population } \\ \text { O } & 45 \\ \text { A } & 41 \\ \text { B } & 10 \\ \text { AB } & 4\end{array}$

We therefore investigated the plasma from group $\mathrm{O}$ donors. This kind of plasma is available in the largest amount, and is known to contain agglutinins for both $\mathrm{A}$ and $\mathrm{B}$ erythrocytes. Its use as a source of anti-A agglutinin ${ }^{5}$ would depend first, on the amount of anti-A antibody present, and second, on the removal of anti-B activity.

\section{Properties of group $O$ plasma}

The results of isoagglutinin titrations of plasma samples obtained from random ${ }^{6}$ donors of groups $O$ and $B$, respectively, are shown in Table II. Considering the probable factors of uncertainty of the ratios, we conclude that when enough donors are represented in the pools to minimize the effect of variations among individuals, an $\mathrm{O}$ plasma pool is approximately equal to a $\mathrm{B}$ pool in its titer against $A_{1}$ cells, and is superior to the $B$ in its titer against $A_{2}$ cells. ${ }^{62}$ These observations, which

5 We use the term "A" generically to include the subgroups $A_{1}, A_{2}$, etc. In a like sense, we use the term "anti-A" to include all of the antibodies effective against A cells.

- Only the following data are excluded from the computations: first, a single test representing a single $O$ donor vs. $A_{1}$ cells, since the plasma was highly hemolytic for these cells; second, tests on plasma from a pool of bloods in which at least one A blood was included by accident.

6a (Note added in proof:) A paper in the German literature (10), recently come to our attention, states that $O$ serum usually agglutinates $A_{2}$ erythrocytes more readily than does $B$ serum, and that $O$ serum has more nearly the same titer $v s$. $A_{1}$ cells on the one hand, and $A_{2}$ cells on the other, than has $B$ serum.
TABLE II

Comparison of $O$ and $B$ plasma titers

\begin{tabular}{c|c|c|c|c|c}
\hline \hline $\begin{array}{c}\text { Cells } \\
\text { used } \\
\text { for } \\
\text { test }\end{array}$ & $\begin{array}{c}\text { Group of } \\
\text { plasma }\end{array}$ & $\begin{array}{c}\text { Number } \\
\text { of donors } \\
\text { repre- } \\
\text { sented }\end{array}$ & $\begin{array}{c}\text { Number* } \\
\text { of tests } \\
\text { per- } \\
\text { formed }\end{array}$ & $\begin{array}{c}\text { Results } \\
\text { Average } \\
\text { ratio of } \\
\text { plasma to } \\
\text { Reference } \\
\text { Standardb }\end{array}$ & $\begin{array}{c}\text { Ratio of } \\
\text { average } \\
\text { titers, } \\
\text { plasma:B } \\
\text { plasma }\end{array}$ \\
\hline $\mathrm{A}_{1}$ & $\mathrm{O}$ & 88 & 31 & 0.24 & 1.3 \\
$\mathrm{~B}$ & 23 & 10 & 0.19 & \\
$\mathrm{~A}_{2}$ & $\mathrm{O}$ & 83 & 13 & 0.75 & 2.6 \\
\hline $\mathrm{B}$ & $\mathrm{B}$ & 22 & 7 & 0.29 & \\
\hline $\mathrm{O}$ & 89 & 32 & 0.15 & \\
\hline
\end{tabular}

- Some plasmas tested were obtained from individual donors; in other cases, plasmas from as many as 12 donors were pooled.

b Comparison with Reference Standard (104B vs. $A_{1}$ and $A_{2}$ cells; $9193 A$ vs. $B$ cells) is not as accurate as comparison with plasma of the other group (last column of the table), since only a few tests were done on the Reference Standards.

are supported in later results representing larger populations, indicate that less than 5 per cent of the total available plasma could be included in a pool of selected B plasma which would match the activity against $A_{2}$ cells of pooled, unselected $O$ plasma, obtained from 45 per cent of all donors.

Removal of anti-B activity from group $O$ plasma

There is considerable antibody in $\mathrm{O}$ plasma that reacts with $B$ erythrocytes. The use of $B$ "soluble substance" for neutralizing this antibody was considered, but it was deemed preferable to remove the undesired isoagglutinin from the system by absorption with B cells. We found it possible to remove the greater part of the anti- $B$ activity by mixing $\mathrm{O}$ plasma with $\mathrm{B}$ cells, or by mixing $\mathrm{O}$ blood with $\mathrm{B}$ cells, or simply by mixing $\mathrm{O}$ blood with $\mathrm{B}$ blood. The absorption was found to be more rapid at room temperature than at $0^{\circ} \mathrm{C}$., and also was found to be faster when larger proportions of $\mathrm{B}$ cells were present. The aim of the absorption, however, is not necessarily the complete removal of anti-B antibody from plasma. Later in the process, residual activity ${ }^{7}$ may be removed,

7 Part of the decrease of anti-B activity during absorption may be due to neutralization of antibody by groupspecific substance present in B plasma (5) or released by B cells. Possibly fractionation of the resulting plasma could result in separation of neutralizing substance from the antibody while concentrating the latter. 
e.g., by reabsorption. Since it is important that plasma resulting from the absorption procedure be suitable for processing into the other products obtained from the fractionation program, it was decided to absorb at $0^{\circ} \mathrm{C}$., and to mix $\mathrm{O}$ and $\mathrm{B}$ bloods, in the same proportion as their relative incidences in the population. Experiments performed under these conditions showed that less than 5 per cent of the original anti-B activity remains after absorption lasting 10 to 15 hours, and that most of the decrease is obtained in about 2 hours.

\section{The agglutinating properties and fractionation of absorbed plasma}

The plasmas resulting from absorption experiments were found to have good anti-A activity, particularly for $\mathrm{A}_{2} \mathrm{~B}$ cells. Tested with these cells, the avidities of the absorbed plasmas were better than the $\mathrm{A}_{2} \mathrm{~B}$ avidity of the anti-A Reference Standard, and the plasmas gave no slide reaction with B cells. However, in one experiment, ${ }^{8}$ satisfactory plasma did not result from a mixture of blood (in this case the anti-B titer was, as usual, very low after absorption, but the anti- $A_{1}$ titer was less than 1 per cent that of Reference Standard) and here it was proved that at least one A blood, in a total number of 69 , had been included by accident with the $\mathrm{O}$ and $\mathrm{B}$ bloods. Thus the importance of eliminating from the pool all cells having the A-agglutinogen, i.e., $\mathrm{A}$ and $\mathrm{AB}$ cells, was demonstrated.

The absorbed plasma was fractionated, and thus it was found that the solubility properties of the anti-A antibody of $\mathrm{O}$ plasma are similar to those of the isoagglutinins from $A$ or $B$ plasma. It was also shown that the remaining anti-B activity could be eliminated by reabsorption, and the resulting anti-A blood-grouping preparations were found to be specific.

\section{LARGE-SCALE EXPERIMENTS UTILIZING}

\section{O PLUS B BLOOD}

It was important to show that the method could be applied to large runs, involving a number of

8 In a run made by one of the cooperating commercial laboratories in August, 1944, the resulting "O plus B" plasma was also poor. Possibly their experience too was caused by the accidental presence of the A-agglutinogen. donors great enough to give statistical validity to the results. These experiments were carried out at the Fort Worth, Texas, Serum Albumin Plant of Armour and Co.'

\section{Blood-grouping procedure}

Since it had been shown that $A$ and $A B$ blood must be excluded from the $O$ plus $B$ pool, each step leading to the preparation of the pool was checked. A double bloodgrouping method 10 based on serology samples received from the Blood Donor Centers was adopted. The first step, the cell-grouping test, was performed on erythrocytes and utilized isoagglutinin reagents. After this preliminary sorting into blood groups was made, all the samples of each single group were retested by a serum-grouping technique, i.e., samples of the individual serums were treated with specially prepared cell suspensions of known groups, and the presence or absence of agglutination was determined. In this way, errors made in the first step were found, and the corresponding samples were rejected. In some of the runs the serum-grouping procedure was also used to reject bloods whose serums hemolysed the test cells. The criteria for hemolytic rejections varied in different cases, and are shown in Table III. In the remaining runs, heated serums resulting from the syphilistesting procedure were used for the serum-grouping test and no hemolytic rejections were made. In no case was rejection based on the strength of the agglutinating reactions obtained, so that in this sense no selection of specimens was made. (See next section, however.)

\section{Blood pooling and separation of plasma}

A pool of all of the group $B$ bloods for each of the $O$ plus $B$ runs was prepared and then mixed with a similar pool of $O$ bloods to start absorption. Since separation of plasma routinely was carried out at $8^{\circ} \mathrm{C}$. at this plant, absorption was done at this temperature. The mixtures were stirred continuously until the end of the time allowed, and then the blood was fed into a battery of centrifuges which continuously separated plasma and cell-rich fractions. Details of the pooling and bloodseparation procedure are given in Table III, which also presents the yields obtained. It will be noted that approximately $280 \mathrm{ml}$. of citrated plasma, containing about 17 grams of plasma protein, were obtained from each donor, regardless of whether O plus B or A bloods were processed. Table III also shows the number of errors detected in the serum-grouping test, and the importance

${ }^{9} \mathrm{We}$ are indebted to Dr. J. D. Porsche for making the arrangements, and to the staff of the plant, especially $\mathrm{Mr}$. A. Koehler, Mr. J. H. Weare, Mr. A. F. Holtorff, Miss M. Slattery, and Mrs. A. Swan for their assistance.

${ }^{10} \mathrm{~A}$ more detailed description of this and later parts of the procedure is included in an Interim Report submitted to the Committee on Medical Research of the Office of Scientific Research and Development. 
TABLE III

Blood grouping, pooling, and centrifugation

\begin{tabular}{|c|c|c|c|c|c|}
\hline \multirow{2}{*}{$\begin{array}{l}\text { Blood groups } \\
\text { Run number }\end{array}$} & \multicolumn{3}{|c|}{ O plus B } & \multicolumn{2}{|c|}{$\mathbf{A}$} \\
\hline & $\begin{array}{l}\text { AI-1, } \\
188\end{array}$ & $\begin{array}{c}\text { AI-2, } \\
190\end{array}$ & $\underset{192}{\text { AI-4, }}$ & Á & $\underset{192}{\text { AI-5, }}$ \\
\hline $\begin{array}{l}\text { Bloods rejected in serum-grouping test: } \\
\text { Number of errors found } \\
\text { O serums causing hemolysis } \\
\text { B serums causing hemolysis }{ }^{\circ} \text { (per cent) }\end{array}$ & $\begin{array}{r}0 \\
40 \\
7\end{array}$ & $\begin{array}{r}4 \\
34 \\
4\end{array}$ & $\begin{array}{r}22 \\
0 \\
0\end{array}$ & 1 & 6 \\
\hline $\begin{array}{l}\text { Blood-pooling: } \\
\text { Total number of donors represented in pools } \\
\text { Ratio, } \mathrm{O} \text { donors: } \mathrm{B} \text { donors in pools }\end{array}$ & $\begin{array}{l}67 \\
4: 2\end{array}$ & $\begin{array}{r}292 \\
\quad 4.5\end{array}$ & $\begin{array}{r}715 \\
4.6\end{array}$ & -278 & 553 \\
\hline $\begin{array}{l}\text { Time allowed for absorption: } \\
\text { Hours elapsed from mixing of } \mathrm{O} \text { and } \mathrm{B} \text { bloods to start of centrifugation } \\
\text { Hours elapsed from mixing of } \mathrm{O} \text { and } \mathrm{B} \text { bloods to end of centrifugation }\end{array}$ & $\begin{array}{l}10 \\
11\end{array}$ & $\begin{array}{l}1 \\
3.2\end{array}$ & $\begin{array}{l}2 \\
5.5\end{array}$ & & \\
\hline $\begin{array}{l}\text { Yields obtained, per donor: } \\
\text { Grams red cell fraction } \\
\text { Milliliters plasma } \\
\text { Grams plasma protein }\end{array}$ & $\begin{array}{c}222 \\
293 \\
17.4\end{array}$ & $\begin{array}{c}237 \\
283 \\
17.2\end{array}$ & $\begin{array}{c}240 \\
274 \\
16.7\end{array}$ & $\begin{array}{c}247 \\
278 \\
16.9\end{array}$ & $\begin{array}{c}230 \\
271 \\
16.4\end{array}$ \\
\hline
\end{tabular}

- After the samples were sorted by grouping the cells, the $O$ and $B$ serums were tested for errors with both $A$ and $B$ cells. Group A serums were checked with B cells only. Bloods cell-grouped as AB were not checked; they were combined with misgrouped bloods and with bloods rejected for causing hemolysis, and were not further included in these experiments.

b $O$ serums which caused any hemolysis of the A cells used in serum-grouping were not included in Run AI-1, 188. For Run AI-2, 190, O serums were not used if they caused complete hemolysis of the A test cells, or any hemolysis of the B test cells. The serums for Run AI-4, 192 were tested after being heated at $56^{\circ} \mathrm{C}$. for 30 minutes, and no hemolysis of test cells was observed.

- One B serum, which hemolyzed the group A test cells, was excluded from Run AI-1, 188. For Run AI-2, 190, B serums were not used if they caused complete hemolysis of the A test cells. Heated serums were tested for Run AI-4, 192 .

d Most of the bloods were drawn less than 2 days before use, and none was older than 3 days.

- In each of the $\mathrm{O}$ plus $\mathrm{B}$ runs, the bloods were pooled before centrifugation. Pools of blood were not made in the A runs, but the plasma was pooled in each case.

Volume of plasma is calculated from the weight obtained, assuming a density of 1.030 for citrated plasma. Protein concentration is calculated by subtracting 0.23 gram $N$ per liter, assumed to be the NPN concentration, from the value obtained by Pregl analysis for the total $\mathrm{N}$ concentration, and multiplying the difference by 6.25 . The results are expressed relative to the number of donors represented in the pools, and have been corrected for known amounts of material removed in processing.

of the double blood-grouping method is thus demonstrated.11

Comparisons of the plasmas and of samples, removed at intervals from the pools and cup-centrifuged, indicated that what hemolysis was obtained could be traced to mechanical factors (e.g., poor behavior of the centrifuges, or too prolonged or too vigorous stirring) and did not correlate with the presence of hemolytic plasma in the pool. Bacterial counts showed that when simple precautions were observed the plasma could be prepared free of detectable contamination.

\section{Agglutinating properties of absorbed plasma}

Isoagglutinin assays of plasma samples from the large-scale experiments are reported in Table IV. Results of titrations are presented in terms of the "titer index," which we define as the negative logarithm, to the base 2, of the highest dilution

11 The evidence suggests that errors were due to mistakes of the persons doing the cell-grouping tests, rather than to weak isoagglutinin preparations. showing agglutination. ${ }^{12}$ Avidity measurements of the speed and extent of agglutination are reported in terms of three observations: the time required for "first visible" agglutination, that for "complete clumping," and the "size" of final clumps obtained. The appearances called "first visible" and "complete clumping" respectively are fixed in terms of the appearances observed at arbitrary times when the cells of known individuals react with the Reference Standards, ${ }^{13}$ and the

12 One advantage of this method of expressing titration results is that the precision, about \pm 1 titer index unit, is easily stated.

13 These determinations were made by delaying the mixing of the faster preparation with its drop of cells by as much time as was needed to bring both preparations being compared to the end-point simultaneously. Repeated trials were necessary to ascertain the time-lag needed, and the precision is judged to be about 5 per cent in the range 20 seconds to 200 seconds. 
TABLE IV

Isoagglutinin assays of plasma samples

\begin{tabular}{|c|c|c|c|c|c|c|c|c|c|c|c|c|c|c|c|c|}
\hline \multirow{2}{*}{ Run } & \multicolumn{4}{|c|}{ O plasma pool } & \multicolumn{4}{|c|}{ B plasma pool } & \multicolumn{4}{|c|}{ 1-hour sample from mixed pool } & \multicolumn{4}{|c|}{ Final plasma } \\
\hline & $\mathbf{T}$ & $\mathbf{F}$ & C & $\mathbf{s}$ & $\mathrm{T}$ & F & $\mathrm{C}$ & s & $\mathrm{T}$ & $\mathrm{F}$ & C & s & $\mathrm{T}$ & F & $\mathrm{C}$ & s \\
\hline \multicolumn{9}{|c|}{ Tested with $A_{1}$ cells. } & \multicolumn{4}{|c|}{ Reference Standard 104B = } & $\overline{9}$ & 5 & 20 & $\lg$ \\
\hline $\begin{array}{l}\text { AI-1 } \\
\text { AI-2 } \\
\text { AI-4 } \\
\text { AI-3 } \\
\text { AI-5 }\end{array}$ & $\begin{array}{l}\overline{8} \\
\overline{7} .5\end{array}$ & $\begin{array}{l}15 \\
13 \\
10\end{array}$ & $\begin{array}{l}55 \\
45 \\
25\end{array}$ & $\begin{array}{l}>\text { sm } \\
<\text { md } \\
>\text { md }\end{array}$ & $\begin{array}{l}8 \\
\frac{7}{8} .5\end{array}$ & $\begin{array}{l}12 \\
12 \\
10\end{array}$ & $\begin{array}{l}33 \\
33 \\
27\end{array}$ & $\begin{array}{r}\text { md } \\
\text { md } \\
>\text { md }\end{array}$ & $\begin{array}{l}7.5 \\
\overline{8}\end{array}$ & $\begin{array}{l}15 \\
12\end{array}$ & $\begin{array}{l}55 \\
32\end{array}$ & $\begin{array}{r}>\mathrm{sm} \\
\mathrm{md}\end{array}$ & $\begin{array}{r}\quad \frac{7.5}{8} \\
<0 \\
<0\end{array}$ & $\begin{array}{r}20 \\
18 \\
13 \\
\\
>300 \\
>300\end{array}$ & $\begin{array}{l}80 \\
65 \\
45\end{array}$ & $\begin{array}{r}\text { sm } \\
>\text { sm } \\
<\text { md }\end{array}$ \\
\hline
\end{tabular}

Tested with $\mathrm{A}_{2} \mathrm{~B}$ cells. Reference Standard 104B $=\overline{\mathbf{5}}$

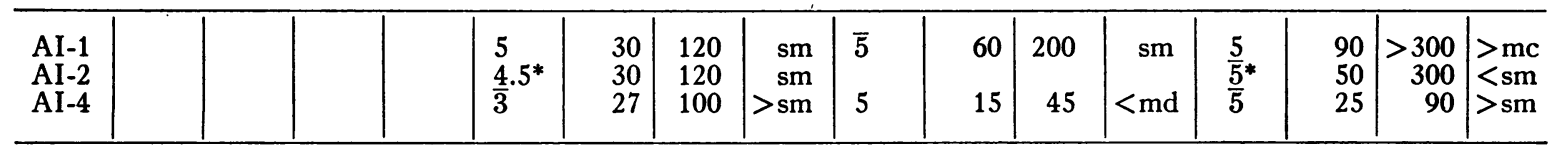

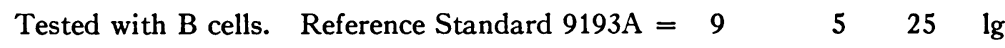

\begin{tabular}{|c|c|c|c|c|c|c|c|c|c|c|c|c|}
\hline $\begin{array}{l}\text { AI-1 } \\
\text { AI-2 } \\
\text { AI-4 } \\
\\
\text { AI-3 } \\
\text { AI-5 }\end{array}$ & $\frac{\overline{7}}{\overline{5}^{*}}$ & $\begin{array}{l}20 \\
50 \\
20\end{array}$ & $\begin{array}{r}100 \\
300 \\
90\end{array}$ & $\begin{array}{l}\text { md } \\
\text { sm } \\
\text { md }\end{array}$ & $<0$ & $\begin{array}{l}>300 \\
>300 \\
>300\end{array}$ & $\begin{array}{l}1.5^{*} \\
1.5^{*}\end{array}$ & $\begin{array}{l}>300 \\
>300\end{array}$ & $\begin{array}{l}0.5 \\
0.5 \\
0.5 \\
\\
6.5^{*} \\
6^{*}\end{array}$ & $\begin{array}{r}>300 \\
>300 \\
>300 \\
50 \\
50\end{array}$ & $\begin{array}{l}300 \\
300\end{array}$ & $\begin{array}{l}\text { sm } \\
\text { sm }\end{array}$ \\
\hline
\end{tabular}

Symbols:

$T$, Titer index. An overlined number means that a weak positive reaction was obtained at the corresponding dilution. $<0$ means no positive reaction was obtained even with undiluted material. * means the titer index is corrected for a slightly different value obtained for the Reference Standard when the test so marked was made.

F, Seconds required for "first visible" macroscopic agglutination to appear in slide test.

C, Seconds required for "complete clumping" to appear in slide test. $>300$ means the corresponding degree of agglutination is not attained in 300 seconds, the maximum duration of the test.

$\mathrm{S}$, Size of final clumps attained in slide test. In ascending order: mc, microscopic; sm, small; md, medium; lg, large. These symbols are modified by $>$, larger than, and $<$, smaller than.

scale of sizes is similarly arbitrarily defined experimentally.

Comparison of the assays ${ }^{14}$ on the group $\mathrm{O}$ plasma samples shows that the best avidity resulted when no rejection for hemolytic reaction of the serum was made, and the same conclusion is indicated for the B plasmas. Further, the avidity, tested with $A_{1}$ cells, of $B$ plasma, where a lower proportion of hemolytic rejections was made, was better in Runs AI-1 and AI-2 than was the corresponding avidity of $\mathrm{O}$ plasma, from which more hemolytic specimens were omitted (compare Table III). However, in Run AI-4, where no hemolytic rejections were made from either group, it was found that $\mathrm{O}$ and $\mathrm{B}$ plasmas

14 These conclusions are largely based on avidity results since the titration method cannot show fine differences unless a larger number of tests are performed. were approximately equal in their avidities for $A_{1}$ erythrocytes. (This may be compared with our earlier statement regarding approximate equality of the titer against $A_{1}$ cells of pooled plasmas of the two groups. ${ }^{15}$ ) The avidities of $B$ plasmas against $\mathrm{A}_{2} \mathrm{~B}$ cells and of $\mathrm{O}$ plasmas against $\mathrm{B}$ cells ${ }^{16}$ also

15 Bryce and Jakobowicz (6) report isoagglutinin determinations on 712 group $O$ donors and 178 group $B$ donors titrated individually against $A_{1}$ cells. After some mathematical assumptions are made, it is possible to show that their data support our conclusion that pooled O plasma is approximately equal or only slightly superior to pooled $\mathrm{B}$ plasma in its activity against these cells. Our data are obtained from a total of 675 group $\mathrm{O}$ donors and 151 group $\mathrm{B}$ donors and all cases where hemolytic rejections were made are excluded.

${ }^{16}$ Comparison of tests with $\mathrm{B}$ cells shows that when no rejections for hemolysis of these cells by $O$ serum were made (Runs AI- 1 and $A I-4$ ), the resulting $O$ plasma was superior to that obtained from A donors (Runs 
support the general conclusion that the more rejections made for hemolytic reactions with erythrocytes, the poorer the resulting pool in its avidity for these erythrocytes. Presumably hemolytic plasmas are among those with the highest individual avidities. ${ }^{17}$ Rejection of hemolytic specimens appears to be a kind of "negative selection."

The plasmas resulting from $O$ plus $B$ mixtures have had more than 95 per cent of the original anti-B antibody removed by the end of the $a b-$ sorption. However, there is in all cases a simultaneous decrease in anti-A avidity. The results, which were checked repeatedly, show that this decrease is progressive; the final plasma is poorer than the 1-hour sample. Our earlier small-scale experiments showed a similar phenomenon in respect to slight progressive decreases in titer as well as avidity. ${ }^{18}$ It has been thought (7) that in some $\mathrm{O}$ plasmas part of the activity against $\mathrm{A}$ cells may be due to a doubly reactive antibody, effective against both the $A$ and the $B$ agglutinogen. Treatment of such plasma with B cells would thus result in removal of this part of the anti-A activity. However, the continued decrease of anti-A avidity between the 1-hour sample, where the anti-B activity is already very low in comparison with the anti-A, and the final plasma makes it doubtful that a doubly-reactive isoagglutinin could alone account for the entire loss obtained. A different explanation of the phenomenon has been offered by Thomsen (8), who states that erythro-

AI-3 and AI-5) in its anti-B activity. This suggests that $O$ plasma may be a useful source of this antibody also (compare Table II). While no $O$ plus $A$ runs have yet been attempted, a plant processing isoagglutinins by the present method would obtain an anti-A yield some onethird larger than its anti-B output. It may be feasible to equalize production by processing $O$ plus $A$ runs.

17 This suggests that if hemolytic plasmas alone were chosen for processing, better material would result. The final isoagglutinin preparation would probably not be hemolytic since all of the components of complement would not be present in this fraction.

18 Not only is it extremely improbable that the A-agglutinogen was present in every case to cause the decrease observed, but the slight drop found, contrasted with the drop to less than 1 per cent of the titer of the Reference Standard in the one experiment where the Aagglutinogen was known to be present, makes it seem that such could hardly be the explanation. It is noteworthy that Fraction III-1-1 was later reabsorbed with $B$ cells with no detectable loss of anti-A avidity. cytes which have reacted with their specific isoagglutinin may then take up other agglutinin by "secondary-binding."

In Run $\mathrm{AI}-4$, where no hemolytic rejections were made, it will be noted that the 1-hour sample of $O$ plus B plasma is superior not only to the $B$ plasma but to the Reference Standard as well when tested with $\mathrm{A}_{2} \mathrm{~B}$ cells. In the other cases, however, due in part to rejection of hemolytic plasmas and in part to decrease in avidity during absorption, the final plasma pools were inferior to the $B$ plasmas alone against $A_{2} B$ cells, and in every case this was so when $A_{1}$ cells were used for the test; yet in every case it was possible to make satisfactory blood-grouping reagents from $\mathrm{O}$ plus B plasma by fractionation, although the yields in the different cases varied because of the different qualities of the plasmas.

\section{Fractionation method}

Each of the plasma pools was separately processed by Method 5 for plasma fractionation. About 26 per cent of the plasma protein nitrogen was present in the isoagglutinin-containing fraction (9), called Fraction II + III, regardless of whether $O$ plus $B$ or A material was processed.

The procedure used for the subfractionation of II + III, Method 7, wasted the prothrombin and the protective antibodies, and will, therefore, be supplanted, so it will here be described only briefly. The isoagglutinins were precipitated 19 under these conditions : $\mathrm{pH} 6.35$, ionic strength 0.005 , room temperature, volume 10 times that of the original plasma, ${ }^{20}$ and ethanol concentration below 0.1 per cent. The precipitate so obtained, called Fraction III-1-1, settled out and was dried from the frozen state. The powder was than redissolved in neutral, isotonic buffer, in a volume one-fifth that of the original plasma, and reabsorbed with group B red cells. Five ml. of the cells, packed by bucket-centrifugation, were used for each liter of plasma represented. The mixture of cells and redissolved Fraction III-1-1 was stirred at $0^{\circ} \mathrm{C}$. continuously for $12 \pm 4$ hours, after which the supernatant, obtained by bucket-centrifugation, was treated with an equal volume of $0^{\circ} \mathrm{C}$. water and filtered through prepared filterpads. It had been noted earlier that losses of activity could result from exhaustive filtration, but assays showed

\footnotetext{
19 For these experiments, the method, devised by Dr. J. L. Oncley and Mr. J. W. Cameron, was modified with the assistance of Dr. D. A. Richert.

20 Only portions of the Fractions II + III from each of the plasmas AI-2, 3, 4, and 5 were subfractionated, and calculations were made accordingly. In these cases, the numeral 1 is suffixed to the plasma numbers to indicate the products of subfractionation.
} 
TABLE V

Isoagglutinin assays of solutions of the intermediate products of fractionation

\begin{tabular}{|c|c|c|c|c|c|c|c|c|c|c|c|c|}
\hline \multirow{2}{*}{ Run } & \multicolumn{4}{|c|}{$\underset{\text { (5-fold over plasma): }}{\text { Fraction III-1-1 }}$} & \multicolumn{4}{|c|}{$\begin{array}{l}\text { Reabsorbed III-1-1 } \\
\text { (5-fold over plasma) }\end{array}$} & \multicolumn{4}{|c|}{$\begin{array}{c}\text { Fractionb III-1-2 } \\
\text { (20-fold over plasma) }\end{array}$} \\
\hline & $\mathrm{T}$ & $\mathbf{F}$ & c & $\mathbf{s}$ & $\mathbf{T}$ & $\mathbf{F}$ & c & s & $\mathbf{T}$ & $\mathbf{F}$ & c & $\mathbf{s}$ \\
\hline \multicolumn{9}{|c|}{ Tested with $A_{1}$ cells. } & $\overline{\mathbf{9}}$ & 5 & 20 & $\lg$ \\
\hline $\begin{array}{l}\text { AI-1 } \\
\text { AI-21 } \\
\text { AI-41 }\end{array}$ & $\frac{\overline{9}}{10}$ & $\begin{array}{r}12 \\
5\end{array}$ & $\begin{array}{l}32 \\
18\end{array}$ & $\begin{array}{l}\mathrm{md} \\
\mathrm{lg}\end{array}$ & $\begin{array}{r}\overline{9} \\
\mathbf{8} \\
10\end{array}$ & $\begin{array}{r}12 \\
5\end{array}$ & $\begin{array}{l}32 \\
18\end{array}$ & $\begin{array}{l}\mathrm{md} \\
\mathrm{lg}\end{array}$ & $\begin{array}{l}10.5 \\
10 \\
10\end{array}$ & $\begin{array}{r}6 \\
6 \\
<5\end{array}$ & $\begin{array}{l}27 \\
22 \\
15\end{array}$ & $\begin{array}{r}\lg \\
>\lg \\
>\lg \end{array}$ \\
\hline $\begin{array}{l}\text { AI-31 } \\
\text { AI-51 }\end{array}$ & & & & & & & & & $\begin{array}{l}<0 \\
<0\end{array}$ & $\begin{array}{l}\text { sp } \\
\text { sp }\end{array}$ & & \\
\hline \multicolumn{9}{|c|}{ Tested with $\mathrm{A}_{2} \mathrm{~B}$ cells. } & $\overline{5}$ & 20 & 75 & sm \\
\hline $\begin{array}{l}\text { AI-1 } \\
\text { AI-21 } \\
\text { AI-41 }\end{array}$ & $\frac{5^{*}}{7}$ & $\begin{array}{l}50 \\
15\end{array}$ & $\begin{array}{r}300 \\
50\end{array}$ & $\begin{array}{l}<\mathrm{sm} \\
<\mathrm{md}\end{array}$ & $\frac{\overline{6}^{*}}{\frac{5}{7}^{*}}$ & $\begin{array}{l}50 \\
15\end{array}$ & $\begin{array}{r}300 \\
50\end{array}$ & $\begin{array}{l}<\mathrm{sm} \\
<\mathrm{md}\end{array}$ & $\begin{array}{l}\overline{7} \\
7^{*} \\
8.5\end{array}$ & $\begin{array}{r}15 \\
15 \\
7\end{array}$ & $\begin{array}{l}60 \\
55 \\
25\end{array}$ & $\begin{array}{c}<m d \\
<\mathrm{lg} d\end{array}$ \\
\hline \multicolumn{9}{|c|}{ Tested with B cells. Reference Standard 9193A = } & 9 & 5 & 25 & $\lg$ \\
\hline $\begin{array}{l}\text { AI-1 } \\
\text { AI-21 } \\
\text { AI-41 }\end{array}$ & $<\frac{0}{2}$ & $\begin{array}{l}>300 \\
>300\end{array}$ & & & $\begin{array}{r}0 \\
<0 \\
<0\end{array}$ & $\begin{array}{l}>300 \\
>300\end{array}$ & & & $\begin{array}{r}\overline{0} \\
\quad<0\end{array}$ & $\begin{array}{l}\text { sp } \\
\text { sp } \\
\text { sp }\end{array}$ & & \\
\hline $\begin{array}{l}\text { AI-31 } \\
\text { AI-51 }\end{array}$ & $\frac{\overline{7}}{8}$ & $\begin{array}{l}15 \\
15\end{array}$ & $\begin{array}{l}60 \\
60\end{array}$ & $\begin{array}{l}\text { md } \\
\text { md }\end{array}$ & & & & & $\begin{array}{l}9 \\
9\end{array}$ & $\begin{array}{l}<5 \\
<5\end{array}$ & $\begin{array}{l}18 \\
18\end{array}$ & $\begin{array}{l}>\lg \\
>\lg \end{array}$ \\
\hline
\end{tabular}

Symbols:

sp: Slide tests for specificity showed no agglutination of the cells indicated, or of group 0 cells, in 7 hours. The slides were stored in a moist chamber at room temperature and were observed microscopically at intervals.

For other symbols, see Table IV.

- All solutions tested were of neutral pH, and isotonic. Their concentration is expressed as " $n$-fold over plasma," where $n$ is equal to the volume of plasma from which the aliquot is obtained divided by the volume of the assayed solution of this aliquot. The yield of isoagglutinin in any fraction may be calculated if this quantity and the titer indexes ( $T$ 's) are known.

b Aliquots of the wet III-1-2 precipitates were tested at $1 / 20$ plasma volume in order to determine what concentration would be needed in each case for the final solution (see Table VI) to exceed the corresponding Reference Standard.

that in these experiments the filtration procedure did not cause detectable loss of activity. The filtrate was reprecipitated under the same conditions as described for the precipitation of Fraction III-1-1. The small amount of hemoglobin introduced during the reabsorption was thus removed, and the resulting Fraction III-1-2 was white. About 3 per cent of the plasma protein nitrogen was obtained in this fraction, i.e., about one-half gram of protein $(\mathrm{N} \times 6.25)$ per donor.

\section{Isoagglutinin assays of the products, and the yields obtained}

While the yields of isoagglutinin obtained by this fractionation procedure were not quantitative, it will be noted that the antibody from $O$ plus $B$ plasma fractionated in the same way as did that from group-specific A plasma, that reabsorption was carried out without loss, and that satisfactory final material resulted. These conclusions are justified by the results reported in Tables $\mathrm{V}$ and VI. It will be noted that each of the preparations was specific for the group of cells with which it was supposed to react.

The yields of the blood-grouping reagents obtained in the different $\mathrm{O}$ plus $\mathrm{B}$ runs increased in the order of the qualities of the plasmas. Table VI shows that, in runs where no exclusion for hemolytic reactions of serum was made, each blood donation processed furnished enough of the corresponding reagent for more than 250 tests. Since routine blood group determinations require equal quantities of the anti-A and the anti-B reagents, the amount of material that may be produced from a given number of blood donations is limited by the incidence of $A$ donors, unless it proves feasible to increase the yield even further by the processing 
TABLE VI

Yields and properties of the blood-grouping reagents

\begin{tabular}{|c|c|c|c|c|c|}
\hline \multirow{2}{*}{ Product number } & \multirow{2}{*}{$\begin{array}{c}\text { Amount } \\
\text { obtained } \\
\text { from each } \\
\text { donor" }\end{array}$} & \multicolumn{4}{|c|}{ Tests onßfinal solution ${ }^{b}$} \\
\hline & & $\mathbf{T}$ & $\mathbf{F}$ & c & $\mathbf{s}$ \\
\hline \multicolumn{2}{|c|}{$\begin{array}{l}\text { Tested with } A_{1} \text { cells. } \\
\text { Reference Standard 104B }=\end{array}$} & $\overline{\boldsymbol{9}}$ & 5 & 20 & $\lg$ \\
\hline $\begin{array}{l}\text { AI-1 (anti-A) } \\
\text { AI-21 (anti-A) } \\
\text { AI-41 (anti-A) }\end{array}$ & $\begin{array}{l}7.4 \mathrm{ml} . \\
10.6 \\
14.0\end{array}$ & $\begin{array}{l}11.5 \\
10 \\
10\end{array}$ & $\begin{array}{l}<5 \\
<5 \\
<5\end{array}$ & $\begin{array}{l}17 \\
17 \\
14\end{array}$ & $\begin{array}{l}>\lg \\
>\lg \\
>\lg \end{array}$ \\
\hline \multicolumn{2}{|c|}{$\begin{array}{l}\text { Tested with } \mathrm{A}_{2} \mathrm{~B} \text { cells. } \\
\text { Reference Standard 104B = }\end{array}$} & $\overline{5}$ & 20 & 75 & sm \\
\hline $\begin{array}{l}\text { AI-1 (anti-A) } \\
\text { AI-21 (anti-A) } \\
\text { AI-41 (anti-A) }\end{array}$ & & $\begin{array}{l}\overline{8} \\
7 \\
8.5\end{array}$ & $\begin{array}{r}10 \\
12 \\
7\end{array}$ & $\begin{array}{l}35 \\
45 \\
25\end{array}$ & $\begin{array}{c}<\text { md } \\
<\text { md } \\
\text { lg }\end{array}$ \\
\hline \multicolumn{2}{|c|}{$\begin{array}{l}\text { Tested with B cells. } \\
\text { Reference Standard 9193A = }\end{array}$} & 9 & 5 & 25 & $\lg$ \\
\hline $\begin{array}{l}\text { AI-31 (anti-B) } \\
\text { AI-51 (anti-B) }\end{array}$ & $\begin{array}{l}13.9 \mathrm{ml} \\
13.6\end{array}$ & $\begin{array}{l}9 \\
9\end{array}$ & $\begin{array}{l}<5 \\
<5\end{array}$ & $\begin{array}{l}18 \\
18\end{array}$ & $\begin{array}{l}>\lg \\
>\lg \end{array}$ \\
\hline \multicolumn{6}{|c|}{$\begin{array}{l}\text { Symbols: } \\
\text { See Table IV. } \\
\text { The finished product is a dried powder. It is prepared } \\
\text { by desiccation from the frozen state of a solution contain- } \\
\text { ing an isotonic mixture of sodium phosphates and chloride, } \\
\text { neutral in pH, and containing Fraction III-1-2 protein in } \\
\text { such a concentration as to provide the required isoagglu- } \\
\text { tinin activity. The product may be dispensed; in what- } \\
\text { ever quantities are convenient; for example it may be } \\
\text { packaged in such amounts as to provide vials containing } \\
1 \text { ml. of blood grouping reagent when reconstituted with } \\
\text { distilled water (or with the diluent containing dye and } \\
\text { preservative specified in Navy contracts). The figure } \\
\text { listed in the table is the number of } 1 \text { ml. vials obtained from } \\
\text { each blood donation processed. A pair of such vials, one } \\
\text { of each group, if used economically, is sufficient for about } \\
20 \text { routine blood group determinations. } \\
\text { b Titer indexes given here are calculated from the results } \\
\text { obtained by titration of the aliquots tested at one-twentieth } \\
\text { of plasma volume (Table V). The avidity measure- } \\
\text { ments were made on the final solution dried. }\end{array}$} \\
\hline
\end{tabular}

of $O$ plus $A$ runs (see footnote 16). If $O$ plus A runs are not processed, a plant receiving 1000 blood donations could produce isoagglutinins from about 800 of these bleedings, and could thus manufacture by the present method about 5000 one ml. vials of each group, a quantity of each reagent sufficient for about 100,000 blood-grouping determinations, provided that the reagents are used economically in the examinations. A number of other products (2) may simultaneously be obtained from these blood donations.

Perhaps the most notable property of the material processed from $\mathrm{O}$ plus $\mathrm{B}$ blood is that it shows relatively little disparity between its reactions with cells having the $A_{1}$ - and the $A_{2}$-agglutinogens, respectively. By contrast, there is a wide difference in reactivity against these different cells in preparations made from group-specific B plasma, ${ }^{21}$ exemplified by the Reference Standard itself (see Tables V and VI). In routine blood group examinations, therefore, all subjects having the Aagglutinogen, regardless of their subgroup, will react in more nearly the same time if the $O$ plus $B$ reagent is employed, and, presumably, the accuracy of such determinations may thereby be increased.

\section{Expert appraisal of the blood-grouping reagents}

Samples of each of the final products were submitted to a number of investigators experienced in the evaluation of such material. Their appraisals are indicated in Table VII. Each investigator employed his own procedures, and his results are therefore compared with his simultaneous determinations of the activities of the corresponding Reference Standards.

\section{SUM MARY}

Pooled plasma from group $\mathrm{O}$ donors, available in larger amount than that from group B donors, is superior to the latter in its activity for red cells having the $A_{2}$-agglutinogen, and is about equal in its activity for $A_{1}$ red cells. The anti-B activity of group $O$ plasma may be removed. Specific anti-A globulin preparations with satisfactory agglutinating properties have been produced from mixtures of $\mathrm{O}$ plus $\mathrm{B}$ blood by methods which are applicable to the large-scale commercial production of blood-grouping reagents.

The author wishes to record his indebtedness to Prof. E. J. Cohn, who directed this project, and to thank Dr. G. Scatchard, Dr. J. F. Enders, Dr. J. T. Edsall, Dr. W. C. Boyd, Dr. L. K. Diamond, Dr. E. L. DeGowin, Dr. J. L. Oncley, Dr. D. A. Richert, and Mr. J. W. Cameron, all of whom suggested improvements in the manuscript. The work here reported was made possible by those whose assistance has already been acknowledged, and by the cooperation of the personnel of the Massachusetts Antitoxin and Vaccine Laboratory and of the Boston Blood Donor Center of the American Red Cross.

21 In this respect, the $O$ plus $B$ material approaches isoimmune $\mathbf{B}$ plasma (prepared by injection of human subjects with soluble group substance), which Dr. W. C. Boyd has shown to react about as well with the $A_{2}$ - as with the $A_{1}$-agglutinogen. 
TABLE VII

Expert appraisal of the blood-grouping reagents, compared with Reference Standards ${ }^{\mathrm{a}}$

\begin{tabular}{|c|c|c|c|c|c|c|c|c|c|c|c|}
\hline \multirow{3}{*}{ Investigator $\mathrm{b}$} & \multirow{3}{*}{$\begin{array}{c}\text { Prep. } \\
\text { number }\end{array}$} & \multicolumn{4}{|c|}{ vs. $A_{1}$ cells } & \multicolumn{4}{|c|}{ vs. $\mathrm{A}_{2} \mathrm{~B}$ cells } & \multirow{3}{*}{ Specificity } & \multirow{3}{*}{ Comment } \\
\hline & & \multirow{2}{*}{$\begin{array}{l}\text { Rel. } \\
\text { titer }\end{array}$} & \multicolumn{3}{|c|}{ Rel. avidity } & \multirow{2}{*}{$\begin{array}{l}\text { Rel. } \\
\text { titer }\end{array}$} & \multicolumn{3}{|c|}{ Rel. avidity } & & \\
\hline & & & (F) & (C) & (S) & & (F) & (C) & $(\mathrm{S})$ & & \\
\hline WCB & $\begin{array}{l}\text { AI-1 } \\
\text { AI-21 } \\
\text { AI-41 }\end{array}$ & \begin{tabular}{l|}
0.5 \\
1 \\
1
\end{tabular} & $\begin{array}{l}2.7 \\
2.7 \\
2.7\end{array}$ & $\begin{array}{l}2.5 \\
2.5 \\
2.8\end{array}$ & $\begin{array}{l}= \\
<\end{array}$ & $\begin{array}{l}0.5 \\
0.5 \\
8\end{array}$ & $\begin{array}{l}2.5 \\
2 \\
2.5\end{array}$ & $\begin{array}{l}2.5 \\
2.1 \\
2.5\end{array}$ & $\begin{array}{l}> \\
= \\
>\end{array}$ & $\begin{array}{l}\text { No reaction } \\
\text { with } \mathrm{B} \text { or } \mathrm{O} \\
\text { cells }\end{array}$ & $\begin{array}{l}\text { These preparations, es- } \\
\text { pecially AI-41, entirely } \\
\text { satisfactory }\end{array}$ \\
\hline $\begin{array}{r}\text { JWC \& } \\
\text { DAR }\end{array}$ & $\begin{array}{l}\text { AI-1 } \\
\text { AI-21 } \\
\text { AI-41 }\end{array}$ & $\begin{array}{l}2 \\
1 \\
2\end{array}$ & $\begin{array}{l}1.3 \\
1 \\
1\end{array}$ & $\begin{array}{l}1.3 \\
1 \\
1\end{array}$ & $\begin{array}{l}> \\
=\end{array}$ & $\begin{array}{l}4 \\
3 \\
6\end{array}$ & $\begin{array}{l}2.5 \\
1.5 \\
2.5\end{array}$ & $\begin{array}{l}2.1 \\
1.2 \\
2.4\end{array}$ & $\begin{array}{l}> \\
>\end{array}$ & & \\
\hline \multirow[t]{2}{*}{ LKD } & $\begin{array}{l}\text { AI }-1 \\
\text { AI }-21 \\
\text { AI }-41\end{array}$ & $\begin{array}{l}4 \\
4 \\
8\end{array}$ & $\begin{array}{l}1.4 \\
1.2 \\
1.8\end{array}$ & $\begin{array}{l}1.3 \\
0.7 \\
1.4\end{array}$ & $\begin{array}{l}= \\
< \\
=\end{array}$ & $\begin{array}{r}16 \\
8 \\
64\end{array}$ & $\begin{array}{l}2.4 \\
1.7 \\
5.5\end{array}$ & $\begin{array}{l}2.6 \\
2 \\
4.5\end{array}$ & $\begin{array}{l}> \\
= \\
>\end{array}$ & $\begin{array}{l}\text { No reaction } \\
\text { with } \mathrm{B} \text { or } \mathrm{O} \\
\text { cells }\end{array}$ & $\begin{array}{l}\text { Excellent } \\
\text { Good } \\
\text { Best of group }\end{array}$ \\
\hline & & \multicolumn{4}{|c|}{ vs. B cells } & & & & & & \\
\hline WCB & $\begin{array}{l}\text { AI-31 } \\
\text { AI-51 }\end{array}$ & $\begin{array}{l}0.5 \\
0.1\end{array}$ & $\begin{array}{l}0.8 \\
0.8\end{array}$ & $\begin{array}{l}1.1 \\
1.1\end{array}$ & $=$ & & & & & $\begin{array}{l}\text { No reaction } \\
\text { with } \mathrm{A} \text { or } \mathrm{O} \\
\text { cells }\end{array}$ & $\begin{array}{l}\text { Quite } \\
\text { satisfactory }\end{array}$ \\
\hline $\begin{array}{r}\text { JWC \& } \\
\text { DAR }\end{array}$ & $\begin{array}{l}\text { AI-31 } \\
\text { AI-51 }\end{array}$ & $\begin{array}{l}1 \\
1\end{array}$ & $\begin{array}{l}1.2 \\
1.2\end{array}$ & $\begin{array}{l}1.1 \\
1.1\end{array}$ & $>$ & & & & & & \\
\hline LKD & $\begin{array}{l}\text { AI-31 } \\
\text { AI-51 }\end{array}$ & $\begin{array}{l}8 \\
4\end{array}$ & $\begin{array}{l}1.5 \\
1.3\end{array}$ & $\begin{array}{l}1.6 \\
1.3\end{array}$ & $\begin{array}{l}= \\
<\end{array}$ & & & & & $\begin{array}{l}\text { No reaction } \\
\text { with } \mathrm{A} \text { or } \mathrm{O} \\
\text { cells }\end{array}$ & $\begin{array}{l}\text { Excellent testing serum } \\
\text { Good }\end{array}$ \\
\hline
\end{tabular}

- The "relative titer" is the ratio between the titer found for the preparation and that found in simultaneous test of the Reference Standard. "Relative avidity" included (F), the ratio between the time required for the Reference Standard to give "first visible" agglutination and the time for the preparation to reach this stage; (C), similarly defined for "complete clumping"; and (S), where we denote whether the preparation gives equal $(=)$, larger $(>)$, or smaller $(<)$ final clumps compared with those given by the Reference Standard. The anti-A preparations were compared with Reference Standard 104B; the anti-B preparations with 9193A.

b Investigators: WCB, Dr. William C. Boyd; JWC \& DAR, Mr. James W. Cameron and Dr. Dan A. Richert; LKD, Dr. Louis K. Diamond.

- The preparations tested were samples of the dried product reconstituted before use.

\section{BIBLIOGRAPHY}

1. Pillemer, L., Oncley, J. L., Melin, M., Elliott, J., and Hutchinson, M. C., Chemical, clinical, and immunological studies on the products of human plasma fractionation. XIII. The separation and concentration of isohemagglutinins from groupspecific human plasma. J. Clin. Invest., 1944, 23, 550.

2. Cohn, E. J., Blood proteins and their therapeutic value. Science, 1945, 101, 51.

3. DeGowin, E. L., Chemical, clinical, and immunological studies on the products of human plasma fractionation. XIV. Appraisal of isohemagglutinin activity. J. Clin. Invest., 1944, 23, 554.

4. Wiener, A. S., Blood Groups and Transfusion. Charles C. Thomas Publishing Company, Springfield, Illinois, 3rd Ed., 1943, p. 304 ; from data of Snyder.

5. Levinson, S. O., and Cronheim, A., Suppression of isoagglutinins. J. A. M. A., 1940, 114, 2097.

Jakobowicz, R., and Bryce, L. M., The iso-agglutinin titre of pooled serum or plasma. M. J. Australia, 1941, I, 318.

Della Vida, B. L., and Dyke, S. C., Absorption of iso- agglutinins from pooled plasma or serum. Lancet, 1941, 1, 564.

6. Bryce, L. M., and Jakobowicz, R., The estimation of the iso-agglutinin titre of human serum, and its practical applications. M. J. Australia, 1941, I, 290.

7. Landsteiner, K., and Witt, D. H., Observations on the human blood groups. J. Immunol., 1926, 11, 221.

Harley, D., Determining the group of human bloodstains. Brit. J. Exper. Path., 1936, 17, 35.

8. Thomsen, O., Ueber die "Sekundärbindung" als Fehlerquelle bei der Herstellung sogenannter "gereinigter Agglutinin-lösungen.” Ztschr. f. Immunitäts., 1931, 70, 140.

9. Cohn, E. J., Oncley, J. L., Strong, L. E., Hughes, W. L., Jr., and Armstrong, S. H., Jr., Chemical, clinical, and immunological studies on the products of human plasma fractionation. I. The characterization of the protein fractions of human plasma. J. Clin. Invest., 1944, 23, 417.

10. Kramer, H., Bestehen qualitative Unterschiede zwischen dem Iso-Anti-A menschlicher O- und BSeren? Ztschr. f. Immunitäts., 1943, 103, 175. 